\title{
Evaluation of Aspergillus tamarii NRC 3 biomass as a biosorbent for removal and recovery of heavy metals from contaminated aqueous solutions
}

\author{
Abdelnaby Mahmoud Saad', Moataza Mahmoud Saad', Nevin Ahmed Ibrahim², Doaa El-Hadedy³,
} Eman Ibrahim Ibrahim¹, Al Zahraa Karam El-Din² and Helmy Mohamed Hassan ${ }^{1 *}$ (D)

\begin{abstract}
Background: Biomass produced as a byproduct from the $\beta$-mannanase production process by Aspergillus tamarii NRC 3 was evaluated as a biosorbent for the removal and recovery of some heavy metal ions.

Results: Under optimal conditions, the isolated strain recorded the highest $\beta$-mannanase activity $\left(31.88 \mathrm{Uml}^{-1}\right)$. Thus, the biomass produced from mannanase production process as a byproduct was evaluated as a biosorbent for the removal and recovery of some heavy metal ions from aqueous solutions and an industrial wastewater. The fungal biomass was found to be efficient for the removal of $\mathrm{Cu}^{+2}$ and some heavy metal ions. The biosorption process of copper(II) by Aspergillus tamarii NRC 3 biomass was affected by changing of time, temperature, $\mathrm{pH}$, metal ions concentration, the presence of some heavy metals, and biomass concentration. The rate of $\mathrm{Cu}^{+2}$ uptake from $\mathrm{Cu}^{+2}$ solution proceeded rapidly, and it appeared to be virtually complete during the initial 5 min (92\%); the maximum uptake of $\mathrm{Cu}^{+2}$ appeared at $30^{\circ} \mathrm{C}, \mathrm{pH} 5$, and biomass concentration $5 \mathrm{~g} \mathrm{w} / \mathrm{W}$. On the other hand, the fungal biomass was to remove considerable proportion of $\mathrm{Pb}^{2+}, \mathrm{Co}^{+2}, \mathrm{Ni}^{2+}, \mathrm{Fe}^{+3}$, and $\mathrm{Cr}^{3+}$ in addition to $\mathrm{Cu}^{2+}$. The uptake of $\mathrm{Cu}^{+2}$ by pretreated biomass was studied. Recovery of the sorbed metal ions by desorbing agents and the potential reuse of the regenerated biomass in metal ions uptake (reloading) were evaluated.
\end{abstract}

Conclusions: Aspergillus tamarii NRC 3 biomass seems to be quite feasible in the removal of heavy metal ions especially $\mathrm{Cu}^{+2}$ from aqueous solutions.

Keywords: Aspergillus tamarii NRC 3, Heavy metal ions, Sorption, Desorption, Reloading

\section{Introduction}

Heavy metal ions are released into the environment by several industrial processes. The continuous production of metal-containing wastewater poses a serious threat to the environment and public health. This is mainly due to their entry and bioaccumulation in food chains (Malik 2004; Chuah et al. 2005). Metal ions such as lead, cadmium, mercury, copper, chromium, zinc, nickel, and cobalt are highly toxic to organisms and have a great impact on the environment

\footnotetext{
* Correspondence: helmymh@hotmail.com

${ }^{1}$ Microbial Chemistry Department, National Research Centre (NRC) (Affiliation ID: 60014618), 33El-Bohouth St., Dokki, Giza, Egypt

Full list of author information is available at the end of the article
}

(Gadd 1993; Volesky and Holan 1995). Copper is the third most used metal in the world and is an essential micronutrient required in the growth of both plants and animals. Copper is indeed essential, but in high doses, it can cause anemia, liver and kidney damage, and stomach and intestinal irritation. Wastewater especially the electrical and electroplating industries contain high levels of $\mathrm{Cu}^{2+}$ and treatment of such waters to remove $\mathrm{Cu}^{2+}$ is needed before disposal (Yilmaz et al. 2010). The conventional methods used for the removal of heavy metals are chemical precipitation, lime coagulation, ion exchange, reverse osmosis, and solvent extraction (Rich and Cherry 1987). These methods are less effective and more expensive when 
metal concentrations are in the range of $1-100 \mathrm{mg} / \mathrm{l}$ (Nourbakhsh et al. 1994). Biosorption by different fungal biomass as biosorbents is a potentially important mechanism for heavy metal clean-up relative to conventional methods due to its low cost, high efficiency, and the possibility of the regeneration and recovery of the metals (Cruz et al. 2004; Luo et al. 2010; doCarmo et al. 2013; Ghosh and Saha 2013). Living as well as dead fungal biomass has been used as biosorbents in the removal of toxic metal ions (Arica et al. 2001 and Saad 2015). It should be mentioned that large amount of fungal biomass are available as byproducts of fermentation industries (antibiotics, organic acids, enzyme production, and biopolymer production for pharmaceutical and food industries). Thus, the waste products from other processes could probably be put to use as biological sorbents (Brown et al. 2001).

The present work was to evaluate the Aspergillus tamarii NRC 3 biomass as a biosorbent for the removal and recovery of some heavy metals from contaminated aqueous solutions and an industrial effluent.

\section{Materials and methods Microorganism}

Aspergillus tamarii NRC 3 was isolated from Egyptian soil and identified by molecular identification using $18 \mathrm{~S}$ rRNA (Saad et al. 2016).

\section{Maintenance of the isolated fungus}

Potato dextrose medium (PDA) was used for maintenance of the isolated fungus. The inoculated slants were incubated for 7 days at $28^{\circ} \mathrm{C}$. The cultures were maintained at $4{ }^{\circ} \mathrm{C}$ and subcultured every 2 weeks.

\section{Culture method}

The spore solution was inoculated into Petri dishes each containing 20-ml PDA medium, $\mathrm{pH}$ 5. The cultures were incubated at $28^{\circ} \mathrm{C}$ for 6 days.

\section{Growth conditions}

One disk (4-mm diameter, equal $2 \times 10^{7}$ spore) was inoculated into a sterilized mannanase production broth medium: modified Czapek's Dox medium contains (g/l) locust bean gum 10.0; $\mathrm{NaNO}_{3}, 2.0 ; \mathrm{K}_{2} \mathrm{HPO}_{4}$, 1.0; $\mathrm{MgSO}_{4} .7 \mathrm{H}_{2} \mathrm{O}, 0.5 ; \mathrm{KCl}, 0.5$; and traces of $\mathrm{FeSO}_{4} .7 \mathrm{H}_{2} \mathrm{O}$ ( $\mathrm{pH} 5)$. The flasks were incubated statically for 6 days at $30{ }^{\circ} \mathrm{C}$. At the end of incubation period, the fungal biomass was separated from the culture by filtration, washed several times with distilled water, and dried between two filter papers to obtain wet biosorbent and the clear supernatant was considered as the crude $\beta$-mannanase enzyme (Saad et al. 2016).
Preparation of heavy metal solutions

The 1000-ppm stock solutions of $\mathrm{Cu}^{2+}, \mathrm{Pb}^{2+}, \mathrm{Co}^{+2}, \mathrm{Ni}^{2+}$, $\mathrm{Fe}^{+3}$,or $\mathrm{Cr}^{3+}$ were made in double distilled water using $\mathrm{CuCl}_{2}, \mathrm{PbCl}_{2}, \mathrm{CoCl}_{2}, \mathrm{NiCl}_{2}, \mathrm{FeCl}_{3}$, or $\mathrm{CrCl}_{3}$ (Merck or $\mathrm{BDH})$. The 10 to $120 \mathrm{ppm}$ solution of $\mathrm{Cu}^{2+}$ and $25 \mathrm{ppm}$ from each tested metal were prepared from $1000 \mathrm{ppm}$ stock solution by dilution with double distilled water.

\section{Analytical methods}

Amount of metal taken up by the biomass was calculated by difference in initial and final concentration in the solution. The residual metal ions were determined by atomic absorption spectrophotometer FS240Agilen.

\section{Heavy metal ions uptake by Aspergillus tamarii NRC 3 biomass \\ General procedure (Saad 2015)}

The pre-cultured fungal biomass $(5 \mathrm{~g}$ wet weight $=0.44 \mathrm{~g}$ dry weight) live or pretreated biomass (dead biomass) was added to $50 \mathrm{ml}$ of metal(s) solution in $250 \mathrm{ml}$ flasks. Duplicates of these flasks were incubated in a shaking incubator at $150 \mathrm{rpm}$ for interval time at $30{ }^{\circ} \mathrm{C}$. A $50-\mathrm{ml}$ metal(s) solution without biomass was incubated in the same manner and stored as control. By the end of the experiment, the content of each flask was filtered through filter papers (Whatman No.1). The biomass was removed from the filter paper, and the supernatant was analyzed for the determination of residual metal(s).

\section{Kinetic and mechanism of $\mathrm{Cu}^{2+}$ uptake by Aspergillus tamarii NRC 3 biomass}

Factors that influence copper(II) uptake by fungal biomass were investigated as follows.

\section{Equilibrium experiments}

In order to determine the maximum time of equilibration for the maximum sorption of $\mathrm{Cu}^{2+}$ by the biomass, several equilibrium experiments were conducted at different times ranging from $5 \mathrm{~min}$ to $120 \mathrm{~min}$.

\section{Effect of $\mathrm{Cu}^{2+}$ concentration}

The dependence of $\mathrm{Cu}^{2+}$ uptake on initial $\mathrm{Cu}^{2+}$ concentration (10-120 $\mathrm{ppm}$ ) was performed at $1 \mathrm{~h}$ period.

\section{Effect of biomass concentration}

The effect of different biomass concentrations (1-5 g wet weight) on the $\mathrm{Cu}^{2+}$ uptake was studied.

\section{Effect of $\mathrm{pH}$}

The effect of $\mathrm{pH}$ on $\mathrm{Cu}^{2+}$ uptake was performed with the range of 3-9 by adjusting the metal solution to the desired $\mathrm{pH}$ with either $0.1 \mathrm{~N} \mathrm{NaOH}$ or $0.1 \mathrm{~N} \mathrm{HCl}$ before adding the biomass. 


\section{Effect of temperature}

The effect of different temperatures $(10,20,30,40$, and $50{ }^{\circ} \mathrm{C}$ ) on the uptake of $\mathrm{Cu}^{2+}$ during $1 \mathrm{~h}$ period was investigated.

\section{Effect of mixed metal ions on $\mathrm{Cu}^{2+}$ uptake}

The effect of a mixture of competing metal ions, i.e., $\mathrm{Pb}^{2+}, \mathrm{Co}^{+2}, \mathrm{Ni}^{2+}, \mathrm{Fe}^{+3}$, and $\mathrm{Cr}^{3+}$ in a concentration of $25 \mathrm{ppm}$ of each metal in addition to $\mathrm{Cu}^{2+}(100 \mathrm{ppm})$ on $\mathrm{Cu}^{2+}$ uptake, was studied. A $50-\mathrm{ml} \mathrm{Cu}{ }^{2+}$ solution in a concentration of $100 \mathrm{ppm}$ with fungal biomass was incubated in the same manner as the control.

\section{Effect of pretreatment of fungal biomass on $\mathrm{Cu}^{2+}$ uptake (Saad 2015)}

Fungal biomass (each $5 \mathrm{~g}$, wet weight $=0.44 \mathrm{~g}$ dry weight) was treated prior to contact with $\mathrm{Cu}^{2+}$ solution (100 ppm of $\left.\mathrm{Cu}^{2+}, \mathrm{pH} 5\right)$ as follows:

1. Boiling with distilled water for $10 \mathrm{~min}$

2. Soaking in $5 \% \mathrm{KOH}$ solution for $10 \mathrm{~min}$, separated by filtration and washed with $1.0 \mathrm{~N} \mathrm{HCl}$ then thoroughly washed several times with distilled water until neutral

3. Soaking in $1.85 \times 10^{-5} \mathrm{mM}$ of sodium azide solution for $30 \mathrm{~min}$, separated by filtration and washed several times with distilled water Appropriate controls for the treatment were prepared and treated simultaneously as the experiments.

\section{Sorption and desorption of mixed metal ions}

Sorption of mixed metal ions, i.e., $\mathrm{Cu}^{2+}, \mathrm{Pb}^{2+}, \mathrm{Co}^{+2}, \mathrm{Ni}^{2+}$, $\mathrm{Fe}^{+3}$, and $\mathrm{Cr}^{3+}$ was carried out as outlined in the general procedure. After initial metal ions uptake, the fungal biomass was separated by filtration and repeatedly washed with distilled water. The metal ions content in the supernatant was determined. The metal ions sorbed by the biomass were taken as $100 \%$ for the subsequent uptake cycle.

The biomass obtained from the initial biosorption (described above) was subjected to desorbing agents $(0.1 \mathrm{~N}$ $\mathrm{HCl}, 0.1 \mathrm{~N} \mathrm{NaHCO}$, or $0.1 \mathrm{~N} \mathrm{Na}_{2} \mathrm{CO}_{3}$ ).

The biomass was suspended in $50 \mathrm{ml}$ of desorbing agent for $1 \mathrm{~h}$. Another $50 \mathrm{ml}$ of desorbing solution without the biomass served as a control. The biomass was separated by filtration. The metal ions content in the supernatant was determined. The elution efficiency of the desorbing agent was calculated as follows:

Elution efficiency \% = amount of desorbed metal ions/ amount of biomass sorbed metal ions $\times 100$
Metal ions uptake by the regenerated biomass

The biomass obtained after the desorption treatment was washed repeatedly with distilled water and re-suspended in $50 \mathrm{ml}$ of metal ions solution for $1 \mathrm{~h}$. Another $50 \mathrm{ml}$ portion of metal ions solution was incubated separately and served as a control. By the end of incubation period, the biomass was separated by filtration and metal ions were determined in supernatant.

Reloading capacity = amount of sorbed metal ions in the second cycle/amount of sorbed metal ions in the first cycle

The experimental procedures above were carried out with each of the desorbing agent in duplicate along with the appropriate controls.

\section{Removal of metal ions from industrial effluent}

An industrial effluent was obtained from the Egyptian Company for leather tanning (El-Basateen, Cairo).

\section{Effluent treatment}

The removal of metal ions from the industrial effluent was carried out as outlines in the general procedure.

\section{Statistical analysis}

Data are expressed as the mean \pm S.E. of three independent culture preparations performed in triplicate. Statistical analysis was achieved using prism software-programmed one-way ANOVA.

\section{Results}

Effect of initial copper(II) concentration

The effect of initial $\mathrm{Cu}^{+2}$ concentration on the $\mathrm{Cu}^{+2}$ uptake by alive fungal biomass was investigated. Figure 1 showed that the amount of $\mathrm{Cu}^{+2}$ uptake by alive fungal biomass increased as the initial concentration increased, and the uptake of $\mathrm{Cu}^{+2}$ was efficient $(96.75 \% \mathrm{ppm}$ ) in solution containing up to $120 \mathrm{ppm} \mathrm{Cu}^{+2}$.

\section{Effect of fungal biomass concentration on $\mathrm{Cu}^{2+}$ uptake}

The amount of copper(II) uptake by fungal biomass increased as the initial biomass concentration increased, and the $\mathrm{Cu}^{+2}$ uptake was efficient (92.40\%) in solution containing $5 \mathrm{~g}$ of wet weight biomass Fig. 2 .

\section{Effect of initial pH on copper(II) uptake}

The effect of initial $\mathrm{pH}$ on $\mathrm{Cu}^{2+}$ uptake by non-growing fungal biomass was examined at pHs $3,5,7$, and $9\left(30^{\circ} \mathrm{C}\right.$ for $1 \mathrm{~h}$ ). Figure 3 showed that the percentage uptake of $\mathrm{Cu}^{2+}$ by fungal biomass decreased at pHs 3,7 , and 9 (34.11, 86.1, and 56.76\%) respectively, while the percentage uptake reached to the maximum at pH 5 (92.51\%). 


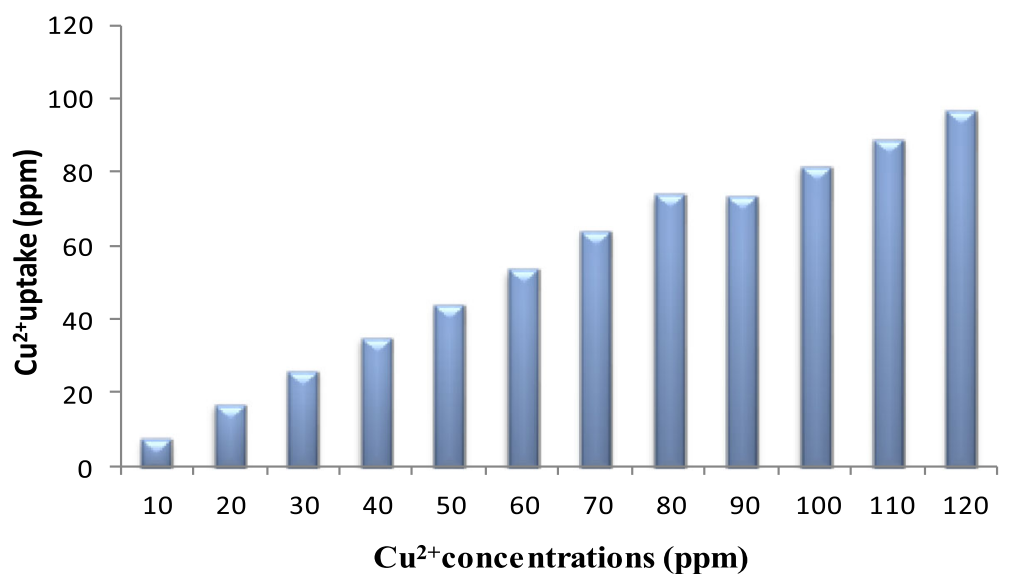

Fig. 1 Effect of $\mathrm{Cu}^{2+}$ concentration on $\mathrm{Cu}^{2+}$ uptake by Aspergillus tamarii $\mathrm{NRC} 3$ biomass (pH 5; temp., $30^{\circ} \mathrm{C}$; rpm, 150; biomass dosage,5 g; contact-time, $1 \mathrm{~h}$ )

\section{Effect of temperature}

The effect of temperature on $\mathrm{Cu}^{2+}$ uptake by fungal biomass was studied in the temperature ranged from 10 to $50{ }^{\circ} \mathrm{C}$. As shown in Fig. 4, the maximum percentages uptake of copper(II) reached to $92.74 \%$ at $30^{\circ} \mathrm{C}$ after $1 \mathrm{~h}$. The decrease of the percentage removal occurred with the decrease and increase of temperature.

Time course of copper(II) uptake by Aspergillus tamarii NRC 3 biomass

Time course of copper uptake by fungal biomass was investigated. Figure 5 indicated that the percentage uptake of $\mathrm{Cu}^{2+}$ from $\mathrm{Cu}^{2+}$ solution was rapid during the first 5 min and it appeared to be virtually complete during the initial $5 \mathrm{~min}(92 \%)$ and then slowly decreased by increasing the incubation time.

\section{Effect of mixed metal ions on copper(II) uptake}

The effect of some heavy metal ions on the $\mathrm{Cu}^{+2}$ uptake by separated alive $A$. tamarii NRC 3 biomass from a solution containing equal concentrations $(25 \mathrm{ppm})$ of $\mathrm{Pb}^{2+}$, $\mathrm{Co}^{+2}, \mathrm{Ni}^{2+}, \mathrm{Fe}^{+3}$, or $\mathrm{Cr}^{3+}$ in addition to $\mathrm{Cu}^{+2}(100 \mathrm{ppm})$ was investigated. As shown in Fig. $6, \mathrm{Cu}^{+2}$ uptakes by fungal biomass were enhanced by $2.38 \%$ in the presence of a mixed metal solution. On the other hand, the fungal biomass removed considerable proportion of $\mathrm{Pb}^{2+}, \mathrm{Co}^{+2}$, $\mathrm{Ni}^{2+}, \mathrm{Fe}^{+3}$, and $\mathrm{Cr}^{3+}$ in addition to $\mathrm{Cu}^{+2}$.

Effect of pretreated biomass on the uptake of copper(II) The uptake of $\mathrm{Cu}^{+2}$ by killed biomass by boiling with water, soaking in $5 \% \mathrm{KOH}$, or soaking in $1.85 \times 10^{-5}$ $\mathrm{NaN}_{3}$ were examined. The experiments were performed to test the effect of metabolic inhibitors on $\mathrm{Cu}^{+2}$ uptake. Results in Table 1 indicated that no considerable changes

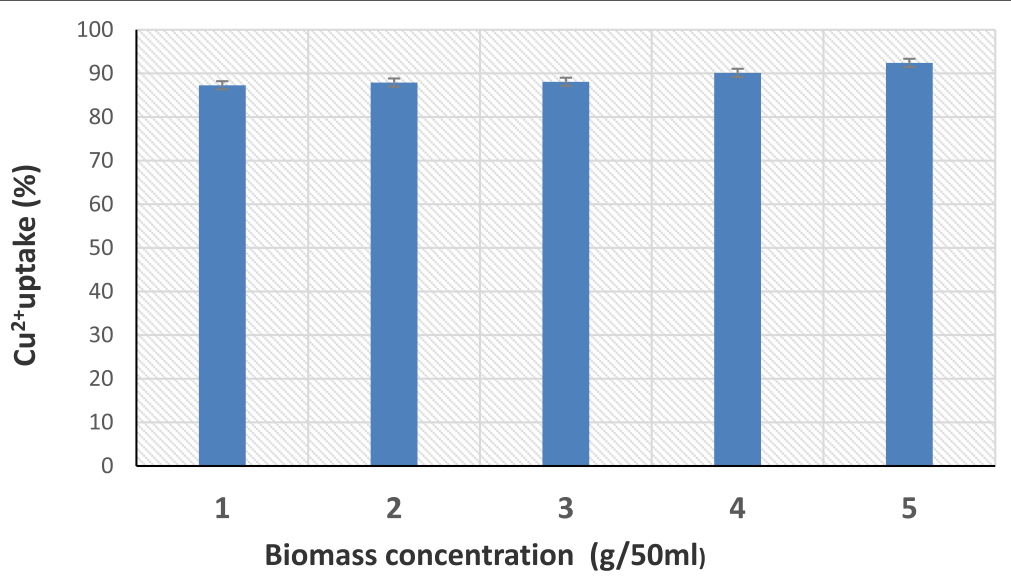

Fig. 2 Effect of biomass concentration on $\mathrm{Cu}^{2+}$ uptake by Aspergillus tamarii NRC 3 biomass ( $\mathrm{Cu}^{2+}$ conc., 80 ppm) 


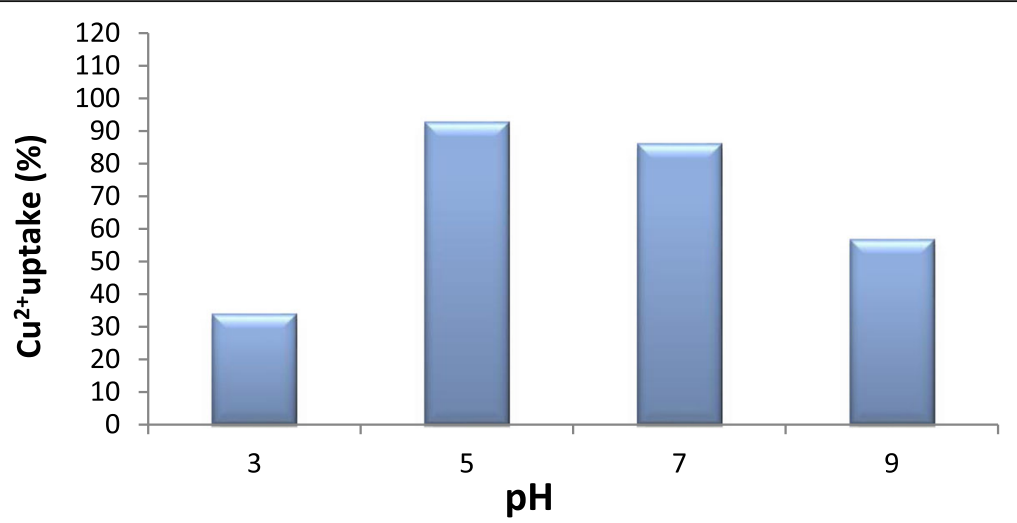

Fig. 3 Effect of initial pH on $\mathrm{Cu}^{2+}$ uptake by Aspergillus tamarii NRC 3 biomass $\left(\mathrm{Cu}^{2+}\right.$ conc., 80 ppm)

in $\mathrm{Cu}^{+2}$ uptake by boiled biomass, while the $\mathrm{Cu}^{+2}$ uptake by soaked biomass in $5 \% \mathrm{KOH}$ or $1.85 \times 10^{-5} \mathrm{NaN}_{3}$ decreased by $5.49 \%$ and $14.96 \%$, respectively.

\section{Metal ions desorption and reloading of fungal biomass}

Recovery of the sorbed metal ions by desorbing agents and the potential reuse of the regenerated biomass in metal ions uptake (reloading) were evaluated.

Data presented in Table 2 showed the effectiveness of the use of $0.1 \mathrm{~N} \mathrm{HCl}, 0.1 \mathrm{~N} \mathrm{NaHCO}_{3}$, or $0.1 \mathrm{~N} \mathrm{Na}_{2} \mathrm{CO}_{3}$ in the desorption of metal ions from fully loaded Aspergillus tamarii NRC 3 biomass. It is to be noted that the initial uptake for metal ions loaded on fungal biomass as indicated in Table 2. Desorption is therefore expressed as percentage removal of metal ions relative to biomass initial loading (Table 2). The greatest efficiency of desorption was observed with the use of $0.1 \mathrm{~N} \mathrm{HCl}\left(\mathrm{Cu}^{+2}\right.$, 61.23\%; $\mathrm{Pb}^{2+}, 69.22 \% ; \mathrm{Co}^{+2}, 37.03 \% ; \mathrm{Ni}^{2+}, 57.65 \% ; \mathrm{Fe}^{+3}$, 43.53\%; and $\mathrm{Cr}^{3+}, 51.48 \%$ ) (Table 2).The regenerated biomass was used for three sorption-desorption cycles. Data presented in Table 3 observed that the uptake of heavy metal ions tested was decreased by the increment of sorption-desorption cycles compared with the initial metals uptake as indicated in Table 2.

\section{Removal of metal ions from an industrial effluent by alive biomass}

The potential use of fungal biomass in pollution control was examined. The effluent containing $\mathrm{Cr}$ as the major heavy metal pollutant beside minor traces of $\mathrm{Cu}, \mathrm{Pb}, \mathrm{Ni}$, $\mathrm{Fe}$, and $\mathrm{Co}$ was used on a small-scale experiment for evaluation of the fungal biomass efficiency in metal ions. From data presented in Table 4, the efficiency of $\mathrm{Cu}^{2+}$ and $\mathrm{Co}^{2+}$ removal was high $(90.94 \%$ and $60.0 \%$, respectively) followed by $\mathrm{Ni}^{2+}, \mathrm{Fe}^{3+}, \mathrm{Pb}^{2+}$, and $\mathrm{Cr}^{3+}(40.0,34.47$, 29.13 , and $11.45 \%$, respectively). It is worth mentioning that the biomass treatment resulted also in the removal of the color and the pungent odor from the effluent. The biomass itself gained the coloration of the effluent.

\section{Discussion}

The active trend towards industrialization and the increased consumption of metals have contributed to heavy metal loads in our natural water systems. As a

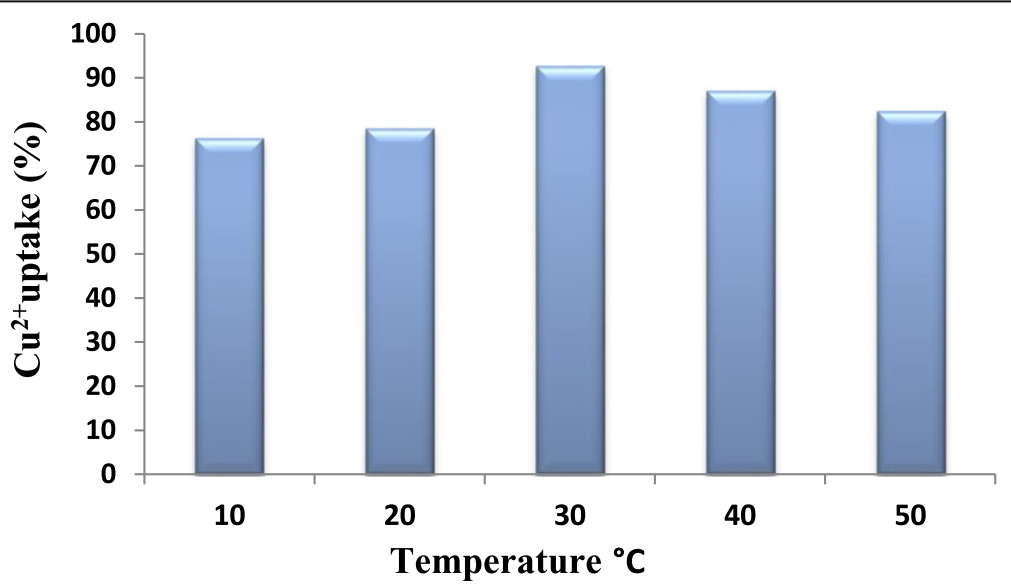

Fig. 4 Effect of temperature ${ }^{\circ} \mathrm{C}$ on $\mathrm{Cu}^{2+}$ uptake by Aspergillus tamarii NRC 3 biomass (Cu ${ }^{2+}$ conc., $80 \mathrm{ppm}$ ) 


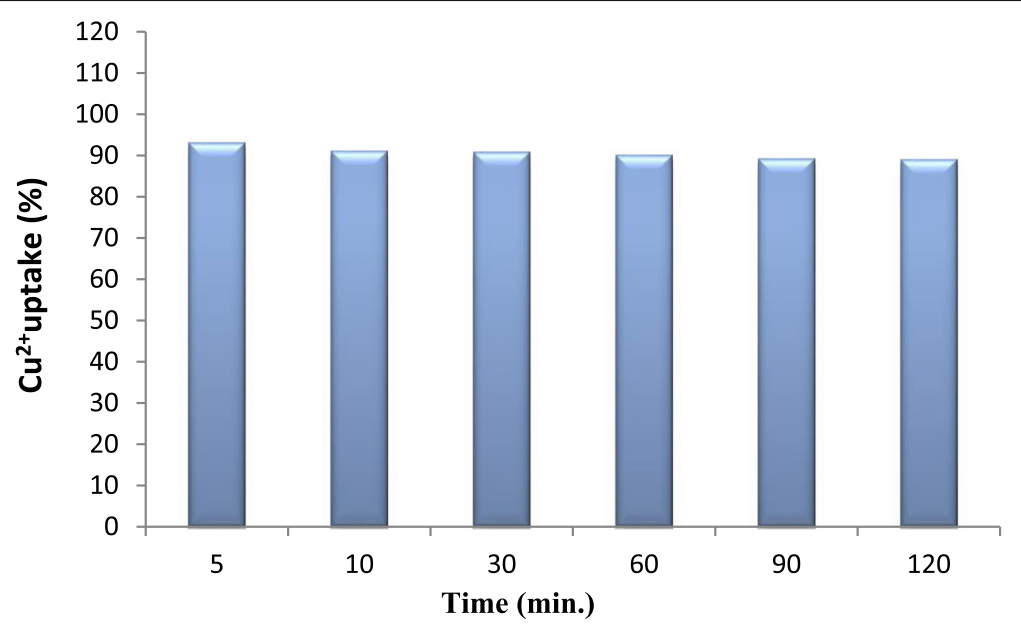

Fig. 5 Effect of time course on $\mathrm{Cu}^{2+}$ uptake by Aspergillus tamarii NRC 3 biomass ( $\mathrm{Cu}^{2+}$ conc., 80 ppm)

result of their toxicity, environmental mobility and complex chemical forms, increasing attention is directed towards studding their removal and recovery from metal-bearing waste streams.

Removal of heavy metals at their source before discharge into receiving water currently depends on physical and chemical means. A recent development in environmental biotechnology is the use of microbial biomass as biosorbents for heavy metals because of the cell wall of fungi which consists of various constituents and the functional groups can make attraction with different types of heavy metals at different concentrations and thus increases the metal sequestration ability of fungi. The effectiveness of the biosorbent depends on the ionic state of the biomass (Gadd 1990; Sakthipriya et al. 2015; Ojuederie and Babalola 2017).

In this study, investigation of kinetic and mechanism of $\mathrm{Cu}^{+2}$ and other heavy metal ions uptake by
Aspergillus tamarii NRC 3 biomass produced as a byproduct from $\beta$-mannanase production was studied.

Evaluation of the effect of initial $\mathrm{Cu}^{+2}$ concentration on the $\mathrm{Cu}^{+2}$ uptake by Aspergillus tamarii NRC 3 biomass was performed. Our results found that the sorption capacity increased and reached to the saturation value as the initial $\mathrm{Cu}^{+2}$ concentration increased in aqueous solution suggesting saturation kinetics with respect to $\mathrm{Cu}^{+2}$ concentration. This result was similar with the results of Iram and Abrar (2015) who observed that by using of Aspergillus flavus and Aspergillus niger biomass as biosorbents, $\mathrm{Cu}^{+2}$ uptake was increased by increasing of initial $\mathrm{Cu}^{+2}$ concentration in aqueous medium. Mukhopadhyay et al. (2007) and Sheng et al. (2007) illustrated that, at high metal ion concentration, the number of ions adsorbed is more than at low metal concentration, where more binding sites were free for interaction. Volesky (1994) reported that the efficiency

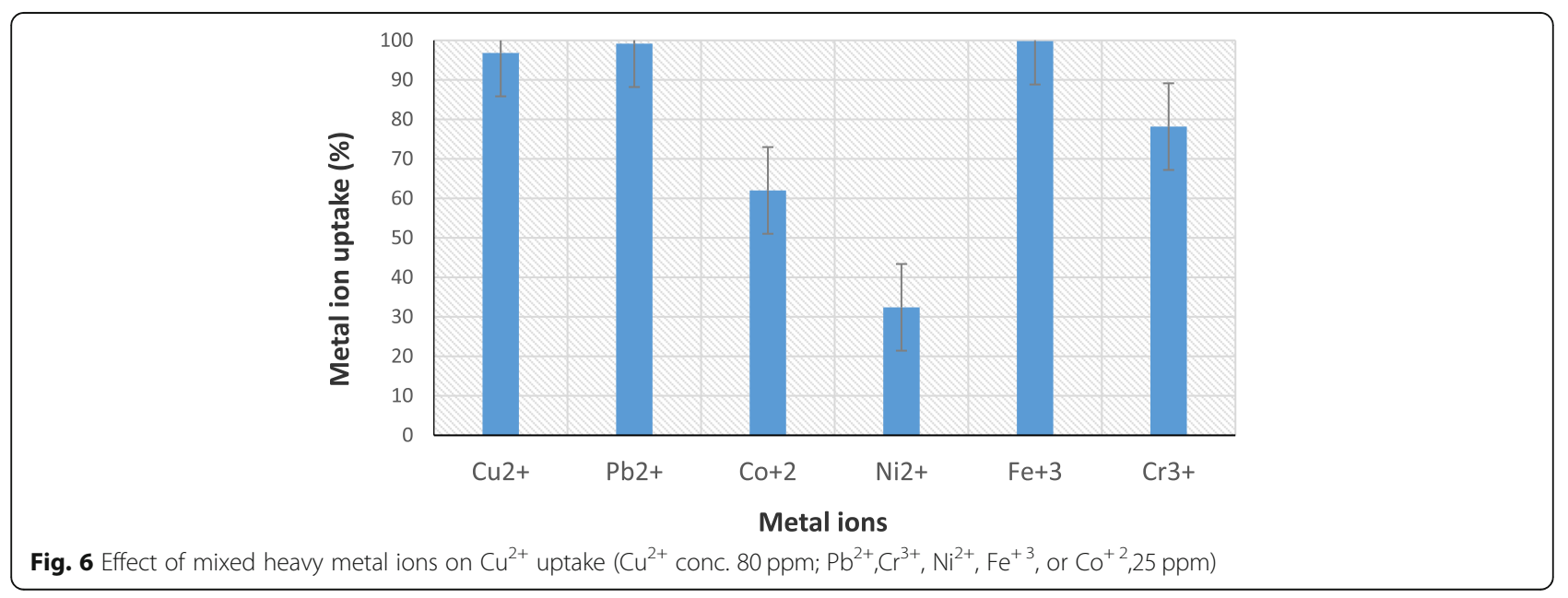


Table $1 \mathrm{Cu}^{2+}$ uptake by alive and dead Aspergillus tamarii NRC 3 biomass

\begin{tabular}{llll}
\hline Biomass & Residual $\mathrm{Cu}^{2+}(\mathrm{ppm}) \pm \mathrm{SD}$ & $\mathrm{Cu}^{2+}$ uptake $(\mathrm{ppm}) \pm \mathrm{SD}$ & $\mathrm{Cu}^{2+} \mathrm{uptake}^{(\%)}$ \\
\hline Alive (control) & $5.12 \pm 0.7$ & $74.88 \pm 7$ & 93.60 \\
Boiled in water for $15 \mathrm{~min}$ & $5.26 \pm 0.8$ & $74.74 \pm 6$ & 93.43 \\
Soaked in $5 \% \mathrm{KOH}$ for $10 \mathrm{~min}$ & $9.51 \pm 1$ & $70.49 \pm 5.5$ & 88.11 \\
Soaked in $1.85 \times 10^{-5} \mathrm{NaN}_{3}$ for $30 \mathrm{~min}$ & $17.09 \pm 1.4$ & $62.91 \pm 6$ & 78.64 \\
\hline
\end{tabular}

Biomass, $5 \mathrm{~g}$; $\mathrm{Cu}^{2+}$ conc. $80 \mathrm{ppm}$

of metal concentration on the biosorbent is influenced by metal solution chemical features.

By testing the effect of different biomass concentrations on $\mathrm{Cu}^{+2}$ uptake process, it was found that the amount of copper(II) uptake by Aspergillus tamarii NRC 3biomass increased as the initial biomass concentration increased. The high uptake efficiency of 5.0-g wet weight biomass may be related to increased surface/volume. Mondal et al. (2017) reported that removal of hexavalent chromium gradually increased with an increment of $A$. niger biomass. Such a trend is mostly attributed to an increase in the absorptive surface area and the availability of more active binding sites on the surface of the adsorbent. Our results agree with those of Siwi et al. (2018) who revealed that the removal efficiency was increased by the increase of initial biosorbent concentration.

The effect of initial $\mathrm{pH}$ of $\mathrm{Cu}^{2+}$ uptake by non-growing fungal biomass was examined. Optimum $\mathrm{pH}$ for maximum $\mathrm{Cu}^{2+}$ uptake by Aspergillus tamarii NRC 3 biomass found to be 5.0 , and the percentage uptake of $\mathrm{Cu}^{2+}$ decreased at $\mathrm{pHs} 3,7$, and 9. This may be related to a competition effect for binding sites between $\mathrm{H}^{+}$and $\mathrm{Cu}^{2+}$. Therefore, it is recommended that $\mathrm{pH}$ control would be necessary to maintain the optimum $\mathrm{pH}$ conditions for metal uptake. Galli et al. (2003) reported that the $\mathrm{pH}$ value of the metal solutions affects the surface charge of the biosorbents and the degree of ionization. Simonescu and Ferdeş (2012) reported that the optimal $\mathrm{pH}$ range for $\mathrm{Cu}^{2+}$ uptake is between 5 and 6.5 which is widely accepted as being optimal for almost all types of fungal biomass.

Table 2 Metal ions desorption by different desorbing agents

\begin{tabular}{lllll}
\hline Metal ion & $\begin{array}{l}\text { Initial metal } \\
\text { ion loaded } \\
\text { on fungal } \\
\text { biomass } \\
\text { (ppm) } \pm \mathrm{SD}\end{array}$ & \multicolumn{3}{l}{ Recovery \% } \\
\cline { 3 - 5 } & $0.1 \mathrm{~N} \mathrm{HCl}$ & $0.1 \mathrm{~N} \mathrm{Na}_{2} \mathrm{CO}_{3}$ & $0.1 \mathrm{~N} \mathrm{NaHCO}_{3}$ \\
\hline $\mathrm{Cu}^{2}$ & $96.08 \pm 8$ & 61.23 & 10.18 & 3.89 \\
$\mathrm{~Pb}^{2+}$ & $24.79 \pm 2$ & 69.22 & 6.37 & 3.43 \\
$\mathrm{Co}^{+2}$ & $15.50 \pm 2$ & 37.03 & 2.06 & 2.00 \\
$\mathrm{Ni}^{2+}$ & $14.05 \pm 3$ & 57.65 & 4.77 & 1.64 \\
$\mathrm{Fe}^{+3}$ & $24.95 \pm 3$ & 43.53 & 17.84 & 5.25 \\
$\mathrm{Cr}^{3+}$ & $19.54 \pm 2$ & 51.48 & 11.92 & 7.37 \\
\hline
\end{tabular}

Biomass, $5 \mathrm{~g}$
Optimal temperature for $\mathrm{Cu}^{2+}$ uptake by fungal biomass was investigated. An increase of biosorption capacity with increasing temperature from 20 to $30^{\circ} \mathrm{C}$ was observed. $\mathrm{Cu}^{2+}$ uptake by Aspergillus tamarii NRC 3 biomass reached to the maximum at $30^{\circ} \mathrm{C}$ which is considered as average height degree, and this may be referred to the higher affinity of $\mathrm{Cu}(\mathrm{II})$ for binding centers, the growing of binding centers from biomass surface as a result of reorientation of fungal biomass cell wall components, and the ionization of chemical groups from cell wall. This result was agreed with the results of Simonescu and Ferdeş (2012) who found that the optimal temperature of $\mathrm{Cu}^{2+}$ biosorption process by Fusarium oxysporum, Aspergillus oryzae ATCC 11489, Aspergillus oryzae ATCC 20423, Aspergillus niger ATCC 15475 , and Polyporus squamosus is $30^{\circ} \mathrm{C}$. Volesky (1990) reported that the physiological state of the organism, the age of the cells, the availability of micronutrients during their growth, and the environmental conditions during the biosorption process (such as $\mathrm{pH}$, temperature, and the presence of certain co-ions) are important parameters that affect the performance of a living biosorbent.

Time course of copper uptake by fungal biomass was investigated. Data indicated that the percentage uptake of $\mathrm{Cu}^{2+}$ from $\mathrm{Cu}^{2+}$ solution was rapid during the first $5 \mathrm{~min}$, and then slowly decreased by increasing the incubation time. There is an initial rapid uptake due to surface adsorption and subsequent slow uptake due to membrane transport of metal ions into cytoplasm of cell or slow intracellular diffusion or reduced permeability of cell wall (Saglam et al. 2002). Similar results were obtained by

Table 3 Metal ions reloading by regenerated biomass

\begin{tabular}{llll}
\hline $\begin{array}{l}\text { Metal ion } \\
\text { concentration } \\
(\mathrm{ppm})\end{array}$ & \multicolumn{3}{l}{ Metal ion reloaded $(\mathrm{ppm})$} \\
\cline { 2 - 4 } & First cycle & Second cycle & Third cycle \\
\hline $\mathrm{Cu}^{2+} 100$ & 61.56 & 57.92 & 50.55 \\
$\mathrm{~Pb}^{2+} 25$ & 16.65 & 15.66 & 12.49 \\
$\mathrm{Co}^{+2} 25$ & 3.16 & 1.17 & 0.55 \\
$\mathrm{Ni}^{2+} 25$ & 2.52 & 1.20 & 0.66 \\
$\mathrm{Fe}^{+3} 25$ & 21.33 & 20.98 & 20.78 \\
$\mathrm{Cr}^{3+} 25$ & 10.86 & 10.14 & 7.04 \\
\hline
\end{tabular}

Regenerated biomass, $5 \mathrm{~g}$ 
Table 4 Removal of heavy metal ions from an industrial effluent by alive Aspergillus tamarii NRC 3 biomass

\begin{tabular}{ll}
\hline $\begin{array}{l}\text { Metal ion content in the } \\
\text { crude industrial effluent (ppm) }\end{array}$ & Metal ion uptake \% \\
\hline $\mathrm{Cu}^{+2} 3.09$ & 90.94 \\
$\mathrm{~Pb}^{+2} 1.27$ & 29.13 \\
$\mathrm{Co}^{+2} 0.45$ & 60.00 \\
$\mathrm{Ni}^{+2} 0.50$ & 40.00 \\
$\mathrm{Fe}^{+2} 2.06$ & 34.47 \\
$\mathrm{Cr}^{+2} 31.52$ & 11.45 \\
\hline
\end{tabular}

Biomass, $5 \mathrm{~g} ; \mathrm{pH}, 5.0$; temp., $30^{\circ} \mathrm{C} ; \mathrm{rpm}, 150$

Chatterjee et al. (2010), Iram and Abrar (2015), and Saad (2015).

The effect of some heavy metal ions on the $\mathrm{Cu}^{+2}$ uptake by separated non-growing $A$. tamarii NRC 3 biomass illustrated that $\mathrm{Cu}^{+2}$ uptake by fungal biomass was enhanced in the presence of a mixed metal solution, and this may be referred to the removal of metals from solutions by fungal biomass as a relatively non-specific process, with each binding site being able to be used by any number of metal species depending on their relative concentration and chemical factors (Gadd 1988; Gang et al. 2012).

By testing the effect of metabolic inhibitors on $\mathrm{Cu}^{+2}$ uptake, the results showed that $\mathrm{Cu}^{+2}$ uptake by boiled biomass or soaked biomass in $5 \% \mathrm{KOH}$ or $1.85 \times 10^{-5} \mathrm{NaN}_{3}$ was decreased. This decline in biosorption process indicating that uptake of $\mathrm{Cu}^{+2}$ by fungal biomass was independent of cellular metabolism. Aksu et al. (1992) reported that extracellular accumulation/precipitation may be facilitated by using viable microorganism, cellsurface sorption or complication can occur with alive or dead microorganisms, while intracellular accumulation requires microbial activity.

Data of recovery of the sorbed metal ions by desorbing agents showed that the greatest efficiency of desorption was observed with the use of $0.1 \mathrm{~N} \mathrm{HCl}$. The ability of mineral acids to act as desorbing agents has been widely demonstrated (Tsezos and Noh 1984; de Rome and Gadd 1991). The results involving desorption would also provide additional support for the view that the biosorption is a physicochemical process. The technical application potential of the metal biosorption process would be substantially enhanced if the potential for recovering the sorbed metal as well as the potential for reusing the regenerated biomass in multiple adsorption-desorption cycles have been developed. Thus, the regenerated biomass was used for three sorption-desorption cycles. Sukumar et al. (2016) reported that the reuse of exhausted adsorbent is extremely important for minimization of metal contamination. Moreover, reusability of spent adsorbent can be assessed by its adsorption performance in successive adsorption-desorption operation.

An effluent from the Egyptian Company for leather tanning which contain $\mathrm{Cr}$ as the major heavy metal pollutant beside minor traces of $\mathrm{Cu}, \mathrm{Pb}, \mathrm{Ni}, \mathrm{Fe}$, and $\mathrm{Co}$ was used on a small-scale experiment for evaluation of the fungal biomass efficiency in metal ions uptake in addition to the removal of the color and the pungent odor from the effluent. The biomass itself gained the coloration of the effluent. Similarly, Chhikara and Dhankhar (2008) reported that biosorption of $\mathrm{Cr}(\mathrm{VI})$ ions from electroplating industrial effluent using immobilized Aspergillus niger biomass was efficient. Jha et al. (2014) found that $\mathrm{Cu}(\mathrm{II})$ uptake by using Aspergillus lentulus biomass from industrial effluents collected from two sources was efficient. Migahed et al. (2017) succeeded in removing all the chromium ions and more than half of the iron ions from both the prepared standard solutions and the real industrial effluents even in the presence of other heavy metals by using a mixture of fungal spores and bacterial biomass in batch and continuous modes to remove lead and chromium ions from the industrial effluents of four different factories.

\section{Conclusion}

Biosorption is a potentially important mechanism for heavy metal clean-up relative to conventional methods due to its low cost, high efficiency, and the possibility of the regeneration and recovery of the metals (Luo et al. 2010; Ghosh and Saha 2013). Thus, the biomass produced from the mannanase production by a local Aspergillus tamarii NRC 3 was used as a biosorbent for the removal, recovery, and reloading of some heavy metal ions from aqueous solutions and as an industrial effluent. Biosorption process of copper(II) by Aspergillus tamarii NRC 3 biomass was affected by changing of time, temperature, $\mathrm{pH}$, metal ions concentration, the presence of some heavy metals, and biomass concentration. These results were agreed with the report of Volesky (1990) who suggested that the physiological state of the organism, the age of the cells, the availability of micronutrients during their growth, and the environmental conditions during the biosorption process (such as $\mathrm{pH}$, temperature, and the presence of certain co-ions) are important parameters that affect the performance of a living biosorbent.

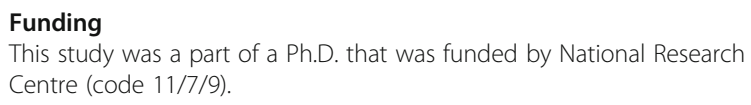

Availability of data and materials

All data and material are available inside manuscript.

Authors' contributions

All authors read and approved the final manuscript. 


\section{Ethics approval and consent to participate}

Not applicable.

\section{Consent for publication}

Not applicable.

\section{Competing interests}

The authors declare that they have no competing interests.

\section{Publisher's Note}

Springer Nature remains neutral with regard to jurisdictional claims in published maps and institutional affiliations.

\section{Author details}

${ }^{1}$ Microbial Chemistry Department, National Research Centre (NRC) (Affiliation ID: 60014618), 33El-Bohouth St., Dokki, Giza, Egypt. ²Department of Microbiology, Faculty of Science, Ain Shams University, Cairo, Egypt. ${ }^{3}$ Microbiology Department, National Center for Radiation Research and Technology, (NCRRT), 3 Ahmed Elzumor St., 8th sector, Madinat Nasr, Cairo 11371, Egypt.

\section{Received: 3 August 2018 Accepted: 4 January 2019}

Published online: 23 January 2019

\section{References}

Aksu Z, Sag Y, Kutsal T (1992) The biosorption of copper by C. Environ Technol 13(6):579-586

Arıca MY, Kaçar Y, Genç Ö (2001) Entrapment of white-rot fungus Trametes versicolor in Ca-alginate beads: preparation and biosorption kinetic analysis for cadmium removal from an aqueous solution. Bioresour Technol 80(2): 121-129

Brown PA, Brown JM, Allen SJ (2001) The application of kudzu as a medium for the adsorption of heavy metals from dilute aqueous waste streams. Bioresour Technol 78(2):195-201

Chatterjee SK, Bhattacharjee I, Chandra G (2010) Biosorption of heavy metals from industrial waste water by Geobacillus thermodenitrificans. J Hazard Mater 175(1-3):117-125

Chhikara S, Dhankhar R (2008) Biosorption of Cr (VI) ions from electroplating industrial effluent using immobilized Aspergillus niger biomass. J Environ Biol 29(5):773-778

Chuah TG, Jumasiah A, Azni I, Katayon S, Choong SYT (2005) Rice husk as a potentially low-cost biosorbent for heavy metal and dye removal: an overview. Desalination 175:305-316

Cruz CCV, da Costa ACA, Henriques CA, Luna AS (2004) Kinetic modeling and equilibrium studies during cadmium biosorption by dead Sargassum sp. biomass Bioresour Technol 91(3):249-257

de Rome L, Gadd GM (1991) Use of pelleted and immobilized yeast and fungal biomass for heavy metal and radionuclide recovery. J Ind Microbiol 7(2):97-104

doCarmo JR, Pimenta CJ, da Silva JF, de Souza SMC (2013) Recovery of copper (II) absorbed in biomass of Cladosporium cladosporioides. Sci Agric 70(3):147-151

Gadd GM (1988) Accumulation of metals by microorganisms and algae. In: Rehm $\mathrm{H}$-J (ed) Biotechnology, Vol. 6b, special microbial processes. VCH V, Weinheim, pp 401-433

Gadd GM (1990) Fungi and yeasts for metal binding. In: Ehrlich H, Brierley CL (eds) Microbial mineral recovery. McGraw-Hill, New York, pp 249-275

Gadd GM (1993) Interactions of fungi with toxic metals. New Phytol 124:25-60

Galli E, Di Mario F, Rapana P, Lorenzoni P, Angelini R (2003) Copper biosorption by Auricularia polytricha. Lett Appl Microbiol 37:133-137

Gang A, Vyas H, Reddy PB, Vyas A (2012) A study of cobalt resistant strains of Neurospora intermedia from Ujjain. Trends Biotechnol Res 1(2):31-34

Ghosh A, Saha PD (2013) Optimization of copper reduction from solution using Bacillus pumilus PD3 isolated from marine water. Elixir Pollution 55: 12910-12914

Iram S, Abrar S (2015) Biosorption of copper and lead by heavy metal resistant fungal isolates. Inter J Sci Res Public 5(1):1-5

Jha S, Chauhan R, Dikshit SN (2014) Fungal biomass as biosorbent for removal of heavy metal from industrial wastewater effluent. Asian J Plant Sci 13(2):93-97

Luo T, Cui J, Hu S, Huang Y, Jing C (2010) Arsenic removal and recovery from copper smelting wastewater using $\mathrm{TiO}_{2}$. Environ Sci Technol 44(23): 9094-9098
Malik A (2004) Metal bioremediation through growing cells. Environ Int 30(2): 261-278

Migahed F, Abdelrazak A, Fawzy G (2017) Batch and continuous removal of heavy metals from industrial effluents using microbial consortia. Int J Environ Sci Technol 14:1169-1180

Mondal NK, Samanta A, Dutta S, Chattoraj S (2017) Optimization of Cr (VI) biosorption onto Aspergillus niger using 3-level Box-Behnken design: equilibrium, kinetic, thermodynamic and regeneration studies. J Genet Eng Biotechnol 15(1):151-160

Mukhopadhyay M, Noronha SB, Suraishkumar GK (2007) Kinetic modeling for the biosorption of copper by pretreated Aspergillus niger biomass. Bioresour Technol 98(9):1781-1787

Nourbakhsh M, Sag̃ Y, Özer D, Aksu Z, Kutsal T, Çãglar A (1994) A comparative study of various biosorbents for removal of chromium $(\mathrm{VI})$ ions from industrial wastewater. Process Biochem 29(1):1-5

Ojuederie OB, Babalola $\mathrm{OO}$ (2017) Microbial and plant-assisted bioremediation of heavy metal polluted environments: a review. Int J Environ Res Public Health 14(12):1504

Rich G, Cherry K (1987) Hazardous waste treatment technologies. Pudvan Publishing Co, Northbrook

Saad AM (2015) Factors affecting cobalt uptake by cobalt-trained Mucor rouxii NRRL 1894 biomass. Eur J Biotechnol Biosci 3(3):1-6

Saad AM, Moataza MS, Hassan HM, Ibrahim NA, El-Hadedy DE, Ibrahim El, Karam El-Din A (2016) Optimization study for $\beta$-mannanase production from locust bean gum by a local Aspergillus tamarii NRC 3 isolate. Res J Pharm Biol Chem Sci 7(6):2597-2609

Saglam A, Yalcinkaya Y, Denizli A, Arica MY, Genc Ö, Bektas S (2002) Biosorption of mercury by carboxymethylcellulose and immobilized Phanerochaete chrysosporium. Microchem J 71:73-81

Sakthipriya N, Doble M, Sangwai J (2015) Bioremediation of coastal and marine pollution due to crude oil using a microorganism Bacillus subtilis. Procedia Engineering 116(1):213-220

Sheng PX, Ting YP, Paul Chen J (2007) Biosorption of heavy metal ions (Pb, Cu and $\mathrm{Cd}$ ) from aqueous solution by the marine alga Sargassum sp., in single and multiple metal systems. Ind Eng Chem Res 46(8):2438-2444

Simonescu CM, Ferdeş M (2012) Fungal biomass for Cu (II) uptake from aqueous systems. Pol J Environ Stud 21(6):1831-1839

Siwi WP, Rinanti A, MDS S, Hadisoebroto R, Fachrul MF (2018) Effect of immobilized biosorbents on the heavy metals $\left(\mathrm{Cu}^{2+}\right)$ biosorption with variations of temperature and initial concentration of waste. The 4th International Seminar on Sustainable Urban Development. IOP Conf. Ser: Earth Environ. Sci 106(1):012113

Sukumar C, Janaki V, Vijayaraghavan K, Kamala-Kannan S, Shanthi K (2016) Removal of $\mathrm{Cr}(\mathrm{VI})$ using co-immobilized activated carbon and Bacillus subtilis: fixed-bed column study. Clean Techn Environ Policy 19(1):251-258

Tsezos M, Noh SH (1984) Extraction of uranium from sea water using biological origin adsorbents. Can J Chem Eng 62(4):559-561

Volesky B (1990) Biosorption and biosorbents, in biosorption of heavy metals. CRC press, Boca Raton, pp 3-5

Volesky B (1994) Advances in biosorption of metals: selection of biomass types. FEMS Microbiol Rev 14(4):291-302

Volesky B, Holan ZR (1995) Biosorption of heavy metals. Biotechnol Prog 11(3): 235-250

Yilmaz M, Tay T, Kivanc M, Turk H (2010) Removal of copper (ii) ions from aqueous solution by a lactic acid bacterium. Braz J Chem Eng 27(2):309-314 